\title{
France takes gentler approach to reforms
}

Declan Butler

\section{By consulting widely on changes in the university sector, France has so far avoided the large-scale protests that met previous attempts.}

T he familiar sight of students and lecturers protesting against university reform on the streets of Paris may be heading for the history books. Last week, for the first time in decades, the French government was able to announce a programme of reform that met with wide consensus rather than resistance.

One possible explanation is that the government has jettisoned its old approach of imposing change from above in favour of broad consultation with all the parties. Another is that the conservative coalition government seems to have abandoned its traditional aim of replacing France's Napoleonic university system, with its cherished principle of open access to all suitably qualified students, with an AngloSaxon model of competitive research at universities with limited student access.

The reforms are the first to emerge from a national consultation process launched by education minister François Bayrou, and aimed at producing a government-endorsed white paper (policy document) on the university system by the end of the year.

The most significant reform is intended to reduce failure rates in the first two years of study leading to a university diploma of general studies. Only 60 per cent of students pass the course, and only one in four of these within the two years, the rest having to resit.

In future, students will receive a more general education in the first semester, enrolling in one of eight broad courses instead of specializing from the outset.

\section{Ambitious construction plans}

Other reforms include streamlining the three-semester academic year into autumn and spring semesters, as in US universities, and an increase in tutorials. There is also a promise to extend the ambitious Université 2000 construction plan - launched in 1991 by Lionel Jospin, the then education minister - under which France has already spent FFr32 billion (US\$5.8 billion) over the past five years to build more than 1.5 million square metres of university space.

The outcome of the first phase of the consultation process has been broadly welcomed by university presidents and students' and teachers' groups, although all are reserving final judgement until specific details are made available about how measures will be implemented and funded. "Bayrou has in the past made promises that were not kept," warns Laurent Bresset, secretary general of the main body representing teachers, the SGEN-CFDT.

This first round of reforms is hardly revolutionary. What is new is the commitment to this and further reform that Bayrou seems to have won from students and staff. In the past, resistance to change from powerful lobbies of students and professeurs has impeded reform efforts. "The changes seem so obvious that you might ask yourself why we didn't do this 15 years ago," says one observer.

Bayrou - a former schoolteacher who is seen as a future presidential candidate appears to have succeeded by consulting widely with all the parties over the past 18 months and hammering out points of consensus. 'La méthode Bayrou', as it is widely called, is the only way to make progress, acknowledges Hélène Lamicq, president of the University of Paris 12-Val-de-Marne.

Yet another reform imposed from above would have been "doomed to fail, no matter what its quality", she says. The government's shift to seeking consensus marks a "real change in a centralized state like France", she says. Bresset says: "It's the first time there have been few criticisms."

Another major change is that the conservatives seem to have abandoned their longstanding goal of creating autonomous universities able to set their own course structures, curricula and fees. At present all universities follow national norms. "This is a historic shift in the policies of the right-wing parties," says Bresset.

Similarly, Bayrou's affirmation of the Centre National de la Recherche Scientifique (CNRS) as a partner of the universities indicates that the government has abandoned plans to dismantle the agency and transfer its laboratories to the universities, says Maurice Gross, CNRS director of university relations.

The government now accepts the concept of a national science community in which both CNRS and the universities have their place, says Gross, providing an environment more conducive to cooperation. "There is a consensus that reform of the universities must take place without endangering organizations that work well," says one observer.

But the task of carrying through this

\section{IMAGE UNAVAILABLE FOR COPYRIGHT REASONS}

Times past? Student protests have been avoided by opting for consensus, not confrontation.

reform remains enormous. Many universities are in a dire state of decay; classrooms are overcrowded, and one in ten buildings fall below minimum safety standards (see Nature 378, 651; 1995).

\section{Are student fees the way ahead?}

Lamicq says she hopes the improved relations between government and the universities will allow the "taboo" subject of student fees to be raised. Many still fear that such a discussion would open a Pandora's box, with universities pressing for fees commensurate with their facilities coming into increasing conflict with critics who argue that substantial fees would contradict the principle of open access.

At present, the state pays 80 per cent of the budget for the universities. But, with general pressure on public spending, the only way universities can boost their income is to increase student fees. Lamicq is convinced that students could be persuaded to accept increases, as long as they were incremental and across the board.

The dilapidated and overcrowded conditions at universities are in stark contrast to the alternative, highly competitive grandes écoles, where students enjoy excellent facilities, including well equipped libraries and laboratories.

In France, the cream of those leaving school undergo a special year of training la classe préparatoire - for the entry competitions to the grandes écoles, while the rest go to university. Yet almost no one, even the students' unions, sees any contradiction between the general acceptance of the grandes écoles and widespread rejection of competitive entry to universities.

"Students accept all selection as long as it is based on merit," explains Bresset, who points out that access to university is automatic for students who succeed in winning a place by passing the school-leaving examination, the baccalauréat. Being excluded from a grande école is acceptable, says one observer, but being excluded totally from higher education is not. 